\title{
Are our youngsters fit? a Botswana perspective To assess tstudent Involvement In Physical activities and Their Social Life.
}

\author{
Jomin George ${ }^{1}$, Sridevi Gangadharan ${ }^{2}$, Aroma Emmanuel ${ }^{3}$ \\ ${ }^{1}$ (Department of Allied Health Sciences, Botho University, Botswana) \\ ${ }^{2}$ (Department of Allied Health Sciences, Botho University,Botswana) \\ ${ }^{3}$ (Department of Allied Health Sciences, Botho University,Botswana)
}

\begin{abstract}
This study sought to evaluate the range of physical activity in university students by conducting a survey and to contribute towards their health promotion by making them more involved in physical activities. Insufficient physical activity is a key risk factor for non-communicable diseases (NCDs) such as cardiovascular diseases, cancer and diabetes. 192 students participated in the study, participants were in the age group of 18 to 21.Number of male participants were less compared to the female. The study pointed out that students are not prioritizing physical activity regardless of the fact that they are studying health related subjects. . Lack of physical activities in childhood and teen age can make a significant impact on a person's growth. These students represented the younger generation of Botswana, who are less fit compared to the older generation. The key factor can be a stagnant lifestyle and electronic gadgets. This situation should change, because the wealth of the country depends on the health of the citizens.
\end{abstract}

Keywords:-Exercise, Fitness, Health, Lifestyle, Non communicable diseases, Physical Activity(PA).

\section{INTRODUCTION}

Physical and mental fitness is very important in a person's life. It makes one healthy and add quality to life. There is a significant difference between the terms physical activity (PA), fitness and exercise. Physical activity can be defined as all bodily movement that leads to energy expenditure. Exercise happens when physical activity is performed in a structured approach with specific aims to increase cardio-respiratory function, muscle strength, muscle endurance and flexibility. Fitness is the consequence of repeated exercise [1]. All exercise can contribute to physical activity, but all physical activity is not exercise.Physically fit people are healthier, compared to those who are not fit. Fitness allows to maintain a healthy body weight and thus reducing the risk of lifestyle diseases. Being physically fit also helps to achieve a good mental balance. Exercising on a daily basis anddepending on a balanced diet can make one physically fit.Physical inactivity is a term used to identify people who do not get the recommended level of regular physical activity [2]. Higher prevalence of physical inactivity can make one prone to high blood pressure, diabetes and cardiac diseases, it also make a person less socially active. This can adversely affect the mental health participation in physical activity has been associated with more favorable biological cardiovascular disease, risk factor profiles (such as lower blood pressure, decreased adiposity, and more favorable serum lipid and lipoprotein levels) and psychological health, such as greater levels of self-esteem and lower levels of stress and anxiety[3].Insufficient physical activity is 1 of the 10 leading risk factors for death worldwide. Insufficient physical activity is a key risk factor for non-communicable diseases (NCDs) such as cardiovascular diseases, cancer and diabetes. Physical activity has significant health benefits and contributes to prevent NCDs. Globally, 1 in 4 adults is not active enough. More than $80 \%$ of the world's adolescent population is insufficiently physically active[4].The purpose of this study was to evaluate the range of physical activity in university students by conducting a survey and to contribute towards their health promotion by making them more involved in physical activities.

1.1 Problem Statement

Younger generation in Botswana is less physically fit compared to the older generation. Fromgeneration Y onwards the vast increase in reliance upon technology results in more time being spent indoors, being lessphysically active[5].Average life expectancy (male/female) in Botswana was 63/65[6].Lack of physical fitness may be a major reason for the inconsistency of life expectancy. Youngsters should be aware of the importance of physical fitness and therefore be motivated to keep them fit. Through this study we tried to analyze the approach of youngsters towards health, and educate them about maintaining their fitness.

\subsection{Objectives}

To evaluate the range of physical activity in university students by conducting a survey and to contribute towards their health promotion by making them more involved in physical activities. 


\section{METHODOLOGY}

The study was carried out in university students who are learning health related courses. A survey was conducted among the students by distributing questionnaires. The questionnaires were distributed through blackboard, the e-Education platform which is used by the students and staff members. 200 questionnaires were distributed and 192 were answered. Participants of the survey was in the age group of 18 to 21 , which is an important phase in their growth. Majority of the participants were female. The survey consisted of questions about health status, diet, weight, physical activity like walking, dancing, jogging, swimming, tobacco and alcohol use, time spend on electronic gadgets, vision problems etc. The section addressing physical activity was elaborative,mainly focusing on how much time the subjects spends on physical activity as well as other activities We did not face any challenges during this survey. The students were clearly informed that the confidentiality will be maintained through-out the survey, even though some students were worried and bit secretive about their answers. Spss version 16.0 was used to interpret the data and analyze the results.

\section{LITERATURE REVIEW.}

World Health organization (WHO)has defined physical activity (PA) as any bodily movement produced by skeletal muscles that requires energy expenditure. Examples for regular moderate intensity physical activity can be "walking, cycling, or participating in sports" which has significant benefits for health. The level of participation in these activities may varies across the agegroups or generations [7].

Benefits of physical activity

Physical activity from childhood through adolescence can contribute to a healthy life style. Health benefits of physical activity include improved body composition and the prevention of overweight and obesity; and improved skeletal, metabolic, and cardiovascular health. Benefits not only are limited to the biological, but also include numerous psychosocial advantages such as a reduction in the symptoms of depression, stress, anxiety, and improvements in self-confidence and self-esteem.Data from large samples ofchildren and adolescents suggest moderate to strong positive associations between theamount of physical activity or participation in physical education and school behavior and academic achievement. [8]

Awareness among students:All students who attended the survey are studying health related courses. They are conscious about the positive changes exercise can bring in life. They are aware of consequences which results from lack of any kind of physical activity.

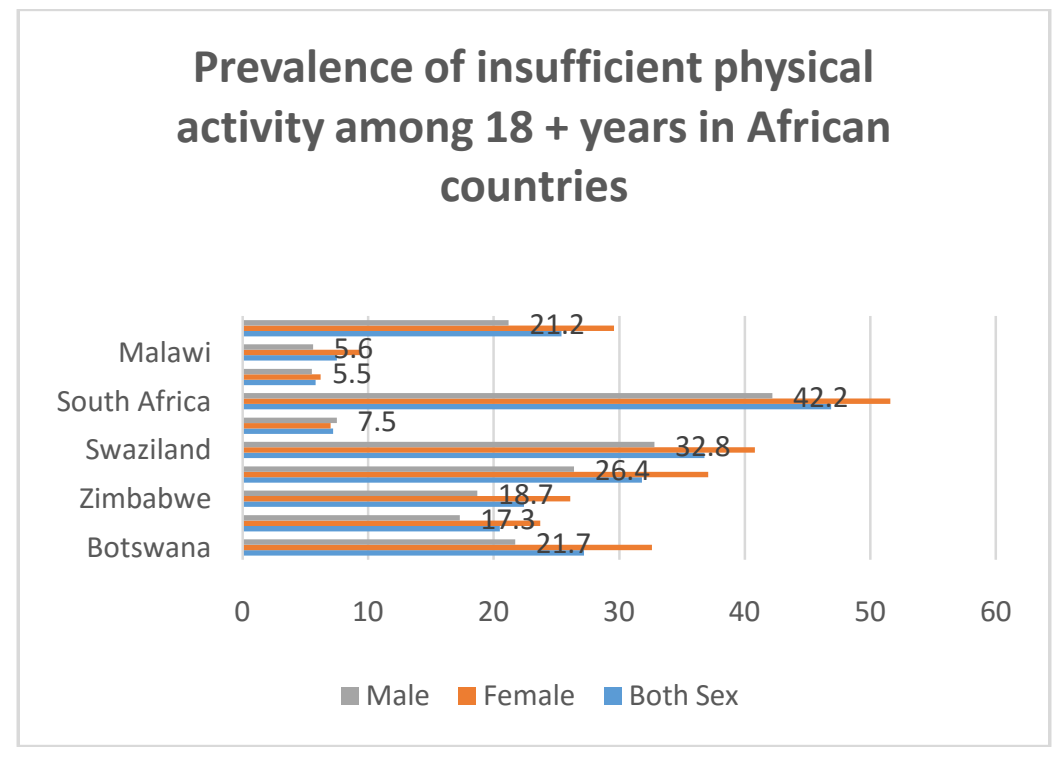

[9]

Need for motivationThe younger generation in Botswana have ample opportunity for exercising regularly. The country's government has provided gym facilities free of cost, also the gym is easy reachable. Students are receiving good support from the university also. The university have basketball court, tennis court and soccer ground which is accessible by the students.

\section{RESULTS}

Table 1 explains the gender of survey participants. Total participants in the survey was 192, out of which 58 were males and 134 were females, which formed $30 \%$ and $70 \%$ of the total participants respectively. 
All participants are currently doing health related courses and were not selected based on any other criteria apart from that.

Table 2 is about the health status of the participants. The students were asked to rate their health status by themselves. Most of them felt their health status is good, and few of them rated it as poor. $11.5 \%$ of them stated it as excellent.

\begin{tabular}{|l|l|l|l|l|l|}
\hline Table 1: Gender & \multicolumn{2}{l|}{} \\
\hline \multirow{3}{*}{ Valid } & Frequency & Percent & Valid Percent & Cumulative Percent \\
\cline { 2 - 6 } & Male & 58 & 30.2 & 30.2 & 30.2 \\
\hline & Female & 134 & 69.8 & 69.8 & 100.0 \\
\cline { 2 - 4 } & Total & 192 & 100.0 & 100.0 & \\
\hline
\end{tabular}

Table 2 : Health status

\begin{tabular}{|c|c|c|c|c|c|}
\hline & & $\begin{array}{l}\text { Freque } \\
\text { ncy }\end{array}$ & $\begin{array}{l}\text { Perce } \\
\text { nt }\end{array}$ & $\begin{array}{l}\text { Valid } \\
\text { Percent }\end{array}$ & $\begin{array}{l}\text { Cumulative } \\
\text { Percent }\end{array}$ \\
\hline \multirow[t]{5}{*}{ Valid } & $\begin{array}{l}\text { Quite } \\
\text { Poor }\end{array}$ & 15 & 7.8 & 7.8 & 7.8 \\
\hline & Averag & 69 & 35.9 & 35.9 & 43.8 \\
\hline & Good & 86 & 44.8 & 44.8 & 88.5 \\
\hline & $\begin{array}{l}\text { Excelle } \\
\text { nt }\end{array}$ & 22 & 11.5 & 11.5 & 100.0 \\
\hline & Total & 192 & $\begin{array}{l}100 . \\
0\end{array}$ & 100.0 & \\
\hline
\end{tabular}

Table 3: Physical activity per week

\begin{tabular}{|c|c|c|c|c|c|}
\hline & & Frequency & Percent & Valid Percent & $\begin{array}{l}\text { Cumulative } \\
\text { Percent }\end{array}$ \\
\hline \multirow[t]{7}{*}{ Valid } & Never & 72 & 37.5 & 37.5 & 37.5 \\
\hline & Once a week & 61 & 31.8 & 31.8 & 69.3 \\
\hline & 2 to 3 times a week & 28 & 14.6 & 14.6 & 83.9 \\
\hline & 4-5 times a week & 13 & 6.8 & 6.8 & 90.6 \\
\hline & 1-3 times a month & 16 & 8.3 & 8.3 & 99.0 \\
\hline & Daily & 2 & 1.0 & 1.0 & 100.0 \\
\hline & Total & 192 & 100.0 & 100.0 & \\
\hline
\end{tabular}

We analyzed thephysical activity of the particpants on a weekly basis. $6.8 \%$ of them get involved in moderate physical activity for about 4-5 times per week.14.6\% of them do that for 2-3 times per week.Physical activity on a daily basis is very less.37.5\% of them does not get involved in any kind of physical activity which is a disappointing fact. It also points out that more awareness and motivation is needed in this matter.

We also made an attempt to know whether the students do the physical activity in their own interest or by a push from someone else. $37.5 \%$ has replied that they are self-inspired. $7.3 \%$ do it with friends. $12 \%$ have membership in a sports club and $5.7 \%$ do the physical activity in their university.

\begin{tabular}{|l|l|r|r|r|r|}
\hline \multicolumn{1}{|c|}{ Table 4: Physical activity in own interest? } \\
\hline \multirow{3}{*}{ Valid } & Frequency & Percent & Valid Percent & $\begin{array}{c}\text { Cumulative } \\
\text { Percent }\end{array}$ \\
\hline & $\begin{array}{l}\text { I don't engage in any } \\
\text { special activity }\end{array}$ & 72 & 37.5 & 37.5 & 37.5 \\
\cline { 2 - 6 } & I do it myself & 72 & 37.5 & 37.5 & 75.0 \\
\hline & Sports Club & 23 & 12.0 & 12.0 & 87.0 \\
\hline & $\begin{array}{l}\text { On self -initiative , with } \\
\text { friend }\end{array}$ & 14 & 7.3 & 7.3 & 94.3 \\
\hline
\end{tabular}




\begin{tabular}{|l|r|r|r|r|}
\hline $\begin{array}{l}\text { University or student } \\
\text { union }\end{array}$ & 11 & 5.7 & 5.7 & 100.0 \\
\hline Total & 192 & 100.0 & 100.0 & \\
\hline
\end{tabular}

The survey also aimed at knowing 'how students spend their spare time apart from studies', we were interested to know whether they are addicted to any kind of drugs or alcohol. Table 5 explains the addiction to tobacco/tobacco products. $83.9 \%$ are not using tobacco/tobacco products which is considerably a good percentage. $3.1 \%$ of the participants are taking more than 5 sticks per day.

But it is an alarming factor that even though it is $3.6 \%$,some students are addicted to alcohol and $66 \%$ of them moderately use alcohol.And $27 \%$ do not use it, which is a good sign. $30.7 \%$ of the participants are also using other drugs like marijuana.

Table 5 : Use of tobacco/tobacco products

\begin{tabular}{|l|l|r|r|r|r|}
\hline & Frequency & Percent & Valid Percent & \multicolumn{2}{|c|}{$\begin{array}{c}\text { Cumulative } \\
\text { Percent }\end{array}$} \\
\hline \multirow{3}{*}{ Valid } & Not at all & 161 & 83.9 & 83.9 & 83.9 \\
\cline { 2 - 7 } & Moderately & 25 & 13.0 & 13.0 & 96.9 \\
\cline { 2 - 6 } & I'm addicted & 3 & 1.6 & 1.6 & 98.4 \\
\cline { 2 - 6 } & I don't know & 3 & 1.6 & 1.6 & 100.0 \\
\cline { 2 - 6 } & Total & 192 & 100.0 & 100.0 & \\
\hline
\end{tabular}

\begin{tabular}{|c|c|c|c|c|c|}
\hline \multicolumn{6}{|c|}{ Table6 : Use of alcohol } \\
\hline & & Frequency & Percent & Valid Percent & $\begin{array}{c}\text { Cumulative } \\
\text { Percent }\end{array}$ \\
\hline \multirow[t]{5}{*}{ Valid } & Not at all & 52 & 27.1 & 27.1 & 27.1 \\
\hline & Moderately & 128 & 66.7 & 66.7 & 93.8 \\
\hline & I'm addicted & 7 & 3.6 & 3.6 & 97.4 \\
\hline & I don't know & 5 & 2.6 & 2.6 & 100.0 \\
\hline & Total & 192 & 100.0 & 100.0 & \\
\hline
\end{tabular}

Table7 : Use of other drugs

\begin{tabular}{|c|c|c|c|c|c|}
\hline & 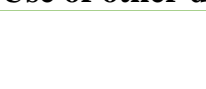 & Frequency & Percent & Valid Percent & $\begin{array}{l}\text { Cumulative } \\
\text { Percent }\end{array}$ \\
\hline \multirow[t]{4}{*}{ Valid } & Not at all & 132 & 68.8 & 68.8 & 68.8 \\
\hline & Moderately & 59 & 30.7 & 30.7 & 99.5 \\
\hline & I don't know & 1 & .5 & .5 & 100.0 \\
\hline & Total & 192 & 100.0 & 100.0 & \\
\hline
\end{tabular}

Table 8: Number of sticks on a daily basis.

\begin{tabular}{|l|l|r|r|r|r|}
\hline & Frequency & Percent & Valid Percent & $\begin{array}{c}\text { Cumulative } \\
\text { Percent }\end{array}$ \\
\hline \multirow{3}{*}{ Valid } & 0 & 162 & 84.4 & 84.4 & 84.4 \\
\cline { 2 - 7 } & $1-2$ sticks & 12 & 6.2 & 6.2 & 90.6 \\
\cline { 2 - 6 } & $3-4$ & 12 & 6.2 & 6.2 & 96.9 \\
\cline { 2 - 6 } & 5 and more & 6 & 3.1 & 3.1 & 100.0 \\
\cline { 2 - 6 } & Total & 192 & 100.0 & 100.0 & \\
\hline
\end{tabular}

Table9: Frequency in which alcohol is taken.

\begin{tabular}{|l|l|r|r|r|r|}
\hline & Frequency & Percent & Valid Percent & \multicolumn{1}{c|}{$\begin{array}{c}\text { Cumulative } \\
\text { Percent }\end{array}$} \\
\hline Valid & Nil & 52 & 27.1 & 27.1 & 27.1 \\
\cline { 2 - 6 } & Once a month or less & 22 & 11.5 & 11.5 & 38.5 \\
\cline { 2 - 6 } & 2-4 times a month & 62 & 32.3 & 32.3 & 70.8 \\
\hline & 2-3 times a week & 49 & 25.5 & 25.5 & 96.4 \\
\hline & $\begin{array}{l}\text { 4 times a week or more } \\
\text { often }\end{array}$ & 7 & 3.6 & 3.6 & 100.0 \\
\hline & Total & 192 & 100.0 & 100.0 & \\
\hline
\end{tabular}


We have seen students spending time on their tablets /laptops and smart phones. Tablets were given by the University for Study Purposes. 50.5\% of the students spend more than 5 hours with their e gadgets on a daily basis which is not healthy. Many of them developed health complications like head ache, shoulder pain, vision problems etc after prolonged use of e gadgets.

\begin{tabular}{|l|l|r|r|r|r|}
\hline \multicolumn{7}{|c|}{ Table10: Time spend on e-gadgets } \\
\hline \multirow{3}{*}{ Valid } & Frequency & Percent & Valid Percent & \multicolumn{1}{c|}{$\begin{array}{c}\text { Cumulative } \\
\text { Percent }\end{array}$} \\
\hline & 0 & 1 & .5 & .5 & .5 \\
\cline { 2 - 7 } & 2 to 3 hours & 3 & 1.6 & 1.6 & 2.1 \\
\cline { 2 - 7 } & 4 to 5 hours & 91 & 47.4 & 47.4 & 49.5 \\
\cline { 2 - 7 } & More than 5 hours & 97 & 50.5 & 50.5 & 100.0 \\
\cline { 2 - 7 } & Total & 192 & 100.0 & 100.0 & \\
\hline
\end{tabular}

\begin{tabular}{|l|l|r|r|r|r|}
\hline \multicolumn{9}{|c|}{ Table11 : Complications after prolonged use of electronic gadgets } \\
\hline \multirow{3}{*}{ Valid } & Frequency & Percent & Valid Percent & $\begin{array}{c}\text { Cumulative } \\
\text { Percent }\end{array}$ \\
\cline { 2 - 6 } & Nil & 16 & 8.3 & 8.3 & 8.3 \\
\cline { 2 - 6 } & Neck pain & 8 & 4.2 & 4.2 & 12.5 \\
\cline { 2 - 6 } & Shoulder pain & 20 & 10.4 & 10.4 & 22.9 \\
\hline & Wrist \& finger pain & 39 & 20.3 & 20.3 & 43.2 \\
\hline \multirow{2}{*}{} & vision problem & 43 & 22.4 & 22.4 & 65.6 \\
\hline & head ache & 66 & 34.4 & 34.4 & 100.0 \\
\hline & Total & 192 & 100.0 & 100.0 & \\
\hline
\end{tabular}

\section{DISCUSSION}

This cross sectional study was conducted as a part of health education and also to motivate the students about giving more importance to physical activity. Total participants were 192, out of which 58 were males and 134 were females. From the results we have found out that students are not prioritizing physical activity. They are studying health related subjects, and very well know about the physical and mental consequences of less physical activity.We were also considered about the increasing workload, whether it can be a reason for less physical activity. But from the study we have found out that more than half of the participants are spending 5 hours with e gadgets on a daily basis, which clearly states that they have time for other activities apart from studying. After spending a long time on studies, it is better to spend time on some kind of physical activity, which can refresh the mind and the body. It can also have a positive impact on health. Being a health student, the participants are aware of that, but still they are not giving importance to physical activity but spending time on e gadgets, which does not give any positiveimpact on their health, also can deteriorate the health by various complications.Students also find time for involving themselves in alcohol and other drugs. They are ready to spend money on that, but not spending time on physical activity, which can enjoyed free of cost.

\section{CONCLUSION}

The study found out that majority of the students are not making use of the facilities given to them. Instead, they spend time in other activities like drinking, smoking and using drugs under boredom or peer pressure. These activities will have a significant impact in one's life in a negative way. This can deteriorate their health, also affect their studies and thus their career. Knowing these facts, the students are still continuing their stagnant life style. Lack of physical activities in childhood and teen age can make a significant impact on a person's growth. Students have been provided with free internet usage and tablets from the university for their study purposes, but they use it for browsing social media and other activities, which can decline the energy and passion for other extra-curricular activities. This statement is supported by the evidence obtained from the results of the study.

Future plans of the team who conducted this study will be to cooperate with the student services and to take this matter further by creating awareness about the negative impact of less physical activity. The team also plansto create motivation among the university students about positive side of the physical activity and thus to contribute for health education in the campus. We believe that once students are educated and motivated, it is easy to spread the message in Botswana by word of mouth. 


\section{REFERENCES}

[1] https://rodwp.pub.coke.com/wpcontent/uploads/sites/55/2014/08/PhysicalActivityTheSouthAfricanConte xt.pdf

[2] http://www.health.ny.gov/diseases/chronic/cvd.htm .

[3] Brown, J.D. \& Siegal, J.M. (1988). Exercise as a buffer of life stress: a prospective study of adolescent health. Health Psychology, 7(4), 341-353.

[4] http://www.who.int/mediacentre/factsheets/fs385/en/

[5] Sotade,O.(2011).Is Gen Y Tech-Savvy or Tech-Dependent?(online) http://healthculturesociety.wikispaces.com/Is+Gen+Y+TechSavvy+or+Tech-Dependent\%3F. July 2014.

[6] http://www.who.int/countries/bwa/en/.

[7] Allman-Farinelli, M., Chey, T., Merom, D., Bowles, H.,Bauman, A. (2008). The effects of age, birth cohort and survey period on leisure-time physical activity by Australian adults:1990-2005. British Journal of Nutrition, 101(4), 609-617.

[8] Tomporowski, Lambourne, \& Okumura (2011)Physical activity interventions and children's mental function: an introduction and overview.Prev Med.2011 Jun;52 Suppl 1:S3-9. doi: 10.1016/j.ypmed.2011.01.028. Epub 2011 Mar 21.

[9] http://apps.who.int/gho/data/node.main.A893?lang=en 